\title{
Plant-soil interactions and acclimation to temperature of microbial-mediated soil respiration may affect predictions of soil $\mathrm{CO}_{2}$ efflux
}

\author{
J. Curiel Yuste $\cdot$ S. Ma $\cdot$ D. D. Baldocchi
}

Received: 8 January 2009/ Accepted: 20 September 2009/Published online: 14 October 2009

(C) The Author(s) 2009. This article is published with open access at Springerlink.com

\begin{abstract}
It is well known that microbial-mediated soil respiration, the major source of $\mathrm{CO}_{2}$ from terrestrial ecosystems, is sensitive to temperature. Here, we hypothesize that some mechanisms, such as acclimation of microbial respiration to temperature and/or regulation by plant fresh $\mathrm{C}$ inputs of the temperature sensitivity of decomposition of soil organic matter (SOM), should be taken into account to predict soil respiration correctly. Specifically, two hypotheses were tested: (1) under warm conditions, temperature sensitivity $\left(\mathrm{Q}_{10}\right)$ and basal rates of microbial-mediated soil respiration $\left(\mathrm{Bs}_{20}\right.$, respiration at a given temperature) would be primarily subjected to presence/absence of plant fresh $\mathrm{C}$ inputs; and (2) under cold conditions, where labile $\mathrm{C}$ depletion occurred more slowly, microbial-mediated soil respiration could adjust its optimal temperatures to colder temperatures (acclimation), resulting in a net increase of respiration rates for a given temperature $\left(\mathrm{Bs}_{20}\right)$. For this purpose, intact soil cores from an oak savanna
\end{abstract}

J. Curiel Yuste · S. Ma · D. D. Baldocchi

Department of Environmental Science, Policy, and

Management, University of California at Berkeley, 137 Mulford Hall, Berkeley, CA 94720, USA

J. Curiel Yuste $(\bowtie)$

Ecophysiology and Global Change Unit CREAF-CEAB-

CSIC, CREAF (Center for Ecological Research and

Forestry Applications), Edifici C, Universitat Autònoma

de Barcelona, 08193 Bellaterra, Spain

e-mail: jcuriel@creaf.uab.es ecosystem were incubated with sufficient water supply at two contrasting temperatures $\left(10\right.$ and $\left.30^{\circ} \mathrm{C}\right)$ during 140 days. To study temperature sensitivity of soil respiration, short-term temperature cycles (from 5 to $40^{\circ} \mathrm{C}$ at $8 \mathrm{~h}$ steps) were applied periodically to the soils. Our results confirmed both hypotheses. Under warm conditions ANCOVA and likelihood ratio tests confirmed that both $\mathrm{Q}_{10}$ and $\mathrm{Bs}_{20}$ decreased significantly during the incubation. Further addition of glucose at the end of the incubation period increased $\mathrm{Bs}_{20}$ and $\mathrm{Q}_{10}$ to initial values. The observed decrease in temperature sensitivity $\left(\mathrm{Q}_{10}\right)$ in absence of labile $\mathrm{C}$ disagrees with the broadly accepted fact that temperature sensitivity of the process increases as quality of the substrate decreases. Our experiment also shows that after 2 months of incubation cold-incubated soils doubled the rates of respiration at cold temperatures causing a strong increase in basal respiration rates $\left(\mathrm{Bs}_{20}\right)$. This suggest that microbial community may have up-regulated their metabolism at cold conditions (cold-acclimation), which also disagrees with most observations to date. The manuscript discusses those two apparent contradictions: the decrease in temperature sensitivity in absence of labile $\mathrm{C}$ and the increase in microbial-mediated soil respiration rates at cold temperatures. While this is only a case study, the trends observed could open the controversy over the validity of current soil respiration models.

Keywords Soil respiration - Carbon cycle modeling $\cdot$ Ecosystem ecology $\cdot$ Climate change 


\section{Introduction}

How climate change will perturb the soil organic carbon (C) reservoir remains a controversy. Microbial-mediated soil respiration, resulting from the decomposition of soil organic matter (SOM) and its transport through the soil, ultimately contributes to an important portion of soil $\mathrm{CO}_{2}$ efflux (Hanson et al. 2000; Bond-Lamberty et al. 2004; Tang and Baldocchi 2005; Hahn et al. 2006). This fact highlights the need to understand physiological mechanisms of microbial metabolism. Biologists have long used exponential functions to describe the temperature dependence of soil respiration, a concept originated in the 19th century physical-chemistry models of Arrhenius (1889) and Van't Hoff (1898). Current models predict that global warming will increase the net $\mathrm{CO}_{2}$ emissions from terrestrial ecosystems due to the strong sensitivity of heterotrophic respiration to temperature (Cox et al. 2000; Friedlingstein et al. 2003; Rustad et al. 2001). However, those models also highlight the large uncertainties associated to predicted soil emissions component (Cox et al. 2000; Cramer et al. 2001; Meir et al. 2006) which are primarily due to the limited, but growing, knowledge of the mechanisms underlying soil respiration (Davidson and Janssens 2006; Davidson et al. 2006).

One of these mechanisms is acclimation, which is the homeostatic adjustment of respiration rates in organisms to compensate for a change in temperature (Atkin et al. 2000). We know that plants can adjust physiologically, by increasing their metabolic activity at low temperatures and/or down-regulating their metabolic activity at warm conditions (Berry and Bjorkman 1980; Atkin and Tjoelker 2003). Concerning soils, it is not yet clear whether microbialmediated soil respiration acclimates to climatic changes and how this acclimation would affect future predictions of terrestrial $\mathrm{CO}_{2}$ emissions. Recent studies have criticized first order kinetics models because they do not reflect the capacity of microbial communities to functionally acclimate to previously unknown environmental conditions (Schimel 1995; Stark and Firestone 1996; Schimel and Gulledge 1998; Balser and Firestone 2001; Hawkes et al. 2005), as has been shown in a number of studies (Zogg et al. 1997; Balser and Firestone 2004; Waldrop and Firestone 2006).
At the ecosystem level, several studies have observed a decrease in soil respiration in association with metabolic down-regulation at warmer temperatures (Luo et al. 2001; Stromgren and Linder 2002; Giardina and Ryan 2000; Misson et al. 2007). However a number of studies have attributed this apparent acclimation to other factors; as temperature increases the imbalance arises between the supply (photosynthesis) and the utilization (respiration) of the most labile $\mathrm{C}$ fraction, product of plant activity (Rustad et al. 2001; Kirschbaum 1995, 2004; Gu et al. 2004; Eliasson et al. 2005; Davidson et al. 2006; Hartley et al. 2007). Recently synthesized sugars contribute substantially to soil respiration (Hogberg et al. 2001; Tang et al. 2005) and provide microbes with the energy to support decomposition of SOM (priming) (Kuzyakov and Cheng 2001, 2004; Fontaine et al. 2003, 2007). Moreover, because our perception of temperature sensitivity of decomposition could be strongly affected by substrate supply at the enzymatic-process level (Davidson and Janssens 2006), it is important to distinguish apparent (observed) from intrinsic (real) temperature sensitivity of soil respiration.

Following these open controversies, we hypothesize that factors not taken into account by current models, such as thermal acclimation of microbial-mediated soil respiration and/or the size of the labile fraction of soil organic matter (SOM) at a given time, may strongly affect soil respiration and its response to temperature. Specifically, we here hypothesize that (1) under warm conditions $\mathrm{Q}_{10}$ (the increase in respiration for every $10^{\circ} \mathrm{C}$ ) and $\mathrm{Bs}_{20}$ (The basal respiration rate for a given temperature) of microbial-mediated soil respiration will be subjected to modulations by plant fresh $\mathrm{C}$ inputs, i.e. the lack of plant fresh $\mathrm{C}$ inputs will affect respiration and its response to temperature negatively; and (2) under cold conditions and more slowly depletion of labile C, soil respiration will increase at lower temperatures with time (acclimation), affecting also $\mathrm{Q}_{10}$ and the $\mathrm{Bs}_{20}$, i.e. as observed in plants, microbial community may adjust their metabolism to new temperatures. For this aim, soils were incubated at two contrasting temperatures, above and below the mean annual temperature, respectively, for 140 days. To investigate possible patterns of acclimation to temperature during the incubation short-term temperature changes were applied periodically to the same soils. 


\section{Materials and methods}

\section{Site description}

Intact soils cores were sampled from an oak savanna field site (Tonzi Ranch), located at $38.4311^{\circ} \mathrm{N}$, $120.966^{\circ} \mathrm{W}$ near Ione, $\mathrm{Ca}$. The altitude of the site is $177 \mathrm{~m}$ and the terrain is relatively flat. The woodland overstory consists of scattered blue oak trees (Quercus douglasii). Also registered in the site survey were occasional grey pine trees (Pinus sabiniana). The understory landscape has been managed, as the local rancher has removed brush and the cattle graze the grass and herbs. The understorey consists of exotic annual grasses and herbs; the species include Brachypodium distachyon, Hypochaeris glabra, Bromus madritensis, and Cynosurus echinatus. Deciduous blue oaks (Quercus douglasii) dominate the savanna site with 144 stem per hectare in a 200 by $200 \mathrm{~m}$ sampling plot. Their average height is $9.41 \pm 4.33 \mathrm{~m}$, and their mean basal area is $0.074 \pm 0.0869 \mathrm{~m}^{2}$ (Chen et al. 2006). The mean annual temperature is $16.3^{\circ} \mathrm{C}$, and $559 \mathrm{~mm}$ of precipitation fall per year, as determined from over 30 years of data from a nearby weather station at Ione, California.

\section{Experimental design}

We decided to sample at peak of biomass and photosynthetic activity (Xu and Baldocchi 2004) when soil metabolic activity is typically at its highest values (Tang and Baldocchi 2005; Curiel Yuste et al. 2007). Intact soil cores were collected on 15 April 2006. By this date, grasses were growing and tree leaves just came out, and mean soil temperature was $\sim 15^{\circ} \mathrm{C}$. Thirty undisturbed soil cores of $80 \mathrm{~cm}^{3}$ $(4 \times 4 \times 5 \mathrm{~cm})$ were collected from the upper part of the soil profile $(0-5 \mathrm{~cm})$ with a soil sampler containing a stainless-steel cylinder within. Soil cores were kept in their stainless steel container to maintain the bulk density and known volume $\left(80 \mathrm{~cm}^{3}\right)$.

Soil cores were collected at 10 sub-locations, five sub-locations randomly chosen in the proximity of a tree (blue oak) and the other five in sub-locations randomly chosen at least $20 \mathrm{~m}$ away from the nearest tree. We did not find important differences in the respiration and its response to temperature $\left(\mathrm{Q}_{10}\right)$ of soils collected in open and under tree areas (data not shown). Therefore, data from both areas were pooled together. Within each sub-location, three pseudoreplicates were taken carefully one next to each-other to avoid large 'environmental' differences (e.g. plant cover, texture) among them. From these soil cores, one was used for incubation at $10^{\circ} \mathrm{C}$ (to test 'coldacclimation'), one was used for incubation at $30^{\circ} \mathrm{C}$ (to test 'warm-acclimation') and the last one was used for analysis (soil water content, soil water potential, total carbon and nitrogen). Therefore, from a total number of 30 cores, ten cores were maintained at $30^{\circ} \mathrm{C}$, other ten were maintained at $10^{\circ} \mathrm{C}$ and the last ten soil cores were used for laboratory analytical studies. Given the number of replicates (ten per treatment), and the methodology used, we can assume that soil cores at cold and warm treatments held the same biogeochemical properties, at the initiation of the incubation treatment.

Because the mean annual temperature $\left(\overline{T_{a}}\right)$ of the ecosystem is around $16^{\circ} \mathrm{C}$ we used these two contrasting temperatures to bound the climatic average. At the time of sample collection, soils were sufficiently moist (Table 1). To avoid water limitations during the incubation period, soil cores were placed within $473 \mathrm{ml}$ glass Mason jars equipped with a continuously water-saturated sponge to keep the soil moistened by capillary action. By continuously maintaining the sponge water-saturated soil moisture was maintained near field capacity during the incubation.

To assess the temperature sensitivity of soil decomposition at different stages of the incubation, four temperature cycles were performed. During a

Table 1 Physical and biochemical properties of the oak savanna soil under study for warm (warm) and cold (cold) incubated soil cores

\begin{tabular}{lll}
\hline & Warm & Cold \\
\hline Dry weight $(\mathrm{g})$ & $132(12)$ & $131(11)$ \\
Soil moisture $(\mathrm{g} / \mathrm{g})$ & $33.5(5.8)$ & $33.8(5.7)$ \\
$\mathrm{N}$ content $(\mathrm{g})$ & $0.25(0.10)$ & $0.25(0.05)$ \\
$\mathrm{C}$ content $(\mathrm{g})$ & $2.7(0.8)$ & $2.7(0.7)$ \\
Bulk density $\left(\mathrm{g} / \mathrm{cm}^{3}\right)$ & $1.5(0.1)$ & $1.4(0.1)$ \\
$\mathrm{C}_{\mathrm{f}}(\mathrm{g})$ & $0.14(0.04)$ & $0.14(0.04)$ \\
$\mathrm{k}_{\mathrm{f}}\left(\mathrm{d}^{-1}\right)$ & $0.05(0.03)$ & 0.01 \\
$\mathrm{k}_{\mathrm{s}}\left(\mathrm{d}^{-1}\right)$ & $1.9 \times 10^{-3}\left(1.0 \times 10^{-4}\right)$ & $4.7 \times 10^{-4}$ \\
\hline $\mathrm{C}_{\mathrm{f}}=$ fast C fraction of soil C; $\mathrm{k}_{\mathrm{f}}=$ rate constants of fast C \\
fraction; $\mathrm{k}_{\mathrm{s}}=$ rate constants of slow C fraction. Numbers in \\
bracket correspond to the standard deviation
\end{tabular}


cycle, temperatures were increased from 5 to $40^{\circ} \mathrm{C}$ and then decreased again to $5^{\circ} \mathrm{C}$ at temperature steps of $5,20,30$ and $40^{\circ} \mathrm{C}$. To ensure temperature equilibration within the soil cores, soil $\mathrm{CO}_{2}$ efflux was measured after $\sim 6-7 \mathrm{~h}$ exposure to the new temperature. To ensure the reliability of the measurements, soil $\mathrm{CO} 2$ efflux was measured two consecutive times at each soil sample and an average of the two measurements was used for later calculations. Therefore, each temperature cycle lasted $\sim 36-$ $42 \mathrm{~h}$. These cycles were performed at 10, 17, 61 and 140 days after the incubation started.

To test the first hypothesis, glucose-a source of labile $\mathrm{C}$-was added to soils depleted of labile C (warm incubated during 140 days). At the end of the incubation period (day 140), five of the soils previously incubated at $30^{\circ} \mathrm{C}$ received $1 \mathrm{ml}$ of a glucose solution $\left(100 \mathrm{mg} \mathrm{ml}^{-1}\right)$. To ensure that the glucose pool did not become exhausted during the temperature perturbation cycle, the quantity added was based on the amount of $\mathrm{CO}_{2}$ depleted during the first temperature cycle. The glucose was injected using a syringe in several locations within the cores to spread the glucose evenly. Two temperature cycles, as described above, were performed before ((-) glucose) and after $((+)$ glucose $)$ the addition of the solution.

\section{Soil analyses}

Bulk density, soil moisture as well as soil carbon (C) and nitrogen $(\mathrm{N})$ concentrations were measured at time 0 using the soil cores spared for analysis. Soil moisture was estimated gravimetrically, by drying the samples during $48 \mathrm{~h}$ at $75^{\circ} \mathrm{C}$. By estimating the dry weight of the soil cores of known volume $\left(80 \mathrm{~cm}^{3}\right)$ we estimated the bulk density of the sample. Results of moisture and $\mathrm{C}$ content of those soil cores were used to calculate the soil moisture and $\mathrm{C}$ content of the incubated soils assuming that the proportion $(\mathrm{g} / \mathrm{g})$ of water and $\mathrm{C}$ were similar for both sets of soils. For more information about soil analyses and methods see Curiel Yuste et al. (2007). Results are presented in Table 1.

\section{Calculation of respiration rates}

We measured soil $\mathrm{CO}_{2}$ efflux using a dynamic flowthrough system which operated under closed and non-steady state conditions. Concentrations of $\mathrm{CO}_{2}$ in the system were measured with a Li-Cor 6262 infrared gas analyzer (Li-Cor, Lincoln, NE). For more information about the system, see Curiel Yuste et al. (2007). Soil respiration was calculated from the linear increase of $\mathrm{CO}_{2}$ concentration within the system with time (normally $40 \mathrm{~s}$ time interval) (Livingston and Hutchinson 1995; Curiel Yuste et al. 2007):

$F_{a}=\frac{\left(\Delta C O_{2}-a\right) \times V_{s}}{t \times A}$

where $\mathrm{F}_{\mathrm{a}}$ is the total soil $\mathrm{CO}_{2}$ evolved from the soil sample during the sampling interval $\left(\mu \mathrm{mol} \mathrm{m} \mathrm{m}^{-2} \mathrm{~s}^{-1}\right)$, $\Delta \mathrm{CO}_{2}$ is the change in $\mathrm{CO}_{2}$ concentration $\left(\mu \mathrm{mol} \mathrm{m}{ }^{-3}\right)$ within the system during the sampling interval, $t$ is the sample interval (s), $a$ is the intercept of the linear function of the relationship between $\mathrm{CO}_{2}$ concentration and time, $\mathrm{V}_{\mathrm{s}}$ is the volume of the system (l) and $\mathrm{A}$ is the area of the upper part of the core $(1.81 \times$ $10^{-3} \mathrm{~m}^{2}$ ). Volume of the system (Vs) was estimated as 0.571 (Curiel Yuste et al. 2007).

Sensitivity to temperature of soil $\mathrm{CO}_{2}$ efflux

To assess the sensitivity to temperature of respiration, we used the $\mathrm{Q}_{10}$ function. $\mathrm{Q}_{10}$ represents the factor by which respiration is multiplied when temperature increases by $10^{\circ} \mathrm{C}$ :

$\mathrm{F}_{\mathrm{a}}=\mathrm{Bs}_{20} \mathrm{Q}_{10}^{\frac{\mathrm{T}-20}{10}}$

Where $F_{a}$ is the measured soil $\mathrm{CO}_{2}$ efflux on area basis $\left(\mu \mathrm{mol} \mathrm{m} \mathrm{m}^{-2} \mathrm{~s}^{-1}\right), \mathrm{Bs}_{20}$ is the basal respiration rate at $20^{\circ} \mathrm{C}$ and $\mathrm{T}$ is the temperature of soil at measurement time. The basal respiration rate was evaluated at $20^{\circ} \mathrm{C}$, a temperature in between both treatments. We fitted this exponential function at each temperature cycle for each soil core individually (warm- and cold-acclimated soil cores) and for the whole temperature range between 5 and $40^{\circ} \mathrm{C}$.

\section{Calculation of soil carbon pools}

There are several equations that can be used to infer the labile and recalcitrant $\mathrm{C}$ pools in soils. In principle, these are based on the changes in the slope of the $\mathrm{C}$ mineralization along the incubation period (Sleutel et al. 2005; Kätterer et al. 1998; Townsend et al. 1997). The method used in this study assumes that the $\mathrm{C}$ mineralized initially had a fast turnover and 
is labile (fast pool), while the remaining fraction has a slow turnover and is recalcitrant (slow pool) (Townsend et al. 1997). We used a two pool first-order kinetics model used in prior works (Breland 1994; Franzluebbers et al. 1994; Bernal et al. 1998):

$$
C_{\text {cum }}(t)=\mathrm{C}_{\mathrm{f}}\left[1-\mathrm{e}^{-\left(\mathrm{k}_{\mathrm{f}} \mathrm{t}\right)}\right]+\left(\mathrm{C}_{\text {total }}-\mathrm{C}_{\mathrm{f}}\right)\left[1-\mathrm{e}^{-\left(\mathrm{k}_{\mathrm{s}} \mathrm{t}\right)}\right]
$$

In Eq. $3 \mathrm{C}_{\text {cum }}(\mathrm{t})$ is the cumulative mineralized $\mathrm{C}$ at a certain time of the incubation, expressed as $\mathrm{F}_{\mathrm{a}}$ $\left(\mathrm{gC} \mathrm{m}^{-2}\right), \mathrm{k}_{\mathrm{f}}$ and $\mathrm{k}_{\mathrm{s}}$ are the decomposition rate of the fast and slow $\mathrm{C}$ pool $\left(\mathrm{d}^{-1}\right), \mathrm{C}_{\mathrm{f}}$ is the carbon content of the fast pool and $\mathrm{C}_{\text {total }}$ the calculated soil $\mathrm{C}$ (Table 2) $\left(\mathrm{Kg} \mathrm{C} \mathrm{m}^{-2}\right)$. $\mathrm{C}_{\text {cum }}$ was calculated for each day using linear interpolation between days where soil respiration was measured. This model gave the best fits out of the three different kinetics models compared in Curiel Yuste et al. (2007). The fit was improved by constraining the size of the slow pool (assumed $\mathrm{C}_{\mathrm{s}}$ as $\mathrm{C}_{\text {total }}-\mathrm{C}_{\mathrm{f}}$ ) (McLauchlan and Hobbie 2004). It should be pointed out that the 'slow pool' in this study refers to a mixture of soil $\mathrm{C}$ pools of very different turnover times, probably from weeks up to centuries or millennia (Trumbore 2000).

We wanted to test whether the differences in respiration rates of cold- and warm-incubated soils could be explained by differences in temperature. To this end we modeled temporal evolution of soil respiration based on observed temporal evolution of soil respiration and temperature sensitivity. Soil respiration in cold-incubated soils did not follow an exponential decay shape (Fig. 1), and therefore the fits and coefficients generated by Eq. 3, when fitted to cold-incubated respiration rates, were not meaningful (data not shown). We, therefore, assumed that: (1) initial values of labile $\mathrm{C}\left(\mathrm{C}_{\mathrm{f}}\right)$ in cold-incubated soils were the same as in warm-incubated soils; (2) decomposition rate were sensitive to temperature with sensitivity equal to a $\mathrm{Q}_{10}$ of 2 (standard value of $\left.\mathrm{Q}_{10}\right)$. We therefore used the decomposition rate $\left(\mathrm{k}_{\mathrm{f}}\right.$ and $\mathrm{k}_{\mathrm{s}}$ ) obtained from fitting warm-incubated soil cores (Eq. 3) and a $\mathrm{Q}_{10}$ function (similar to Eq. 2) to model the decomposition rate of labile and recalcitrant pools of the cold incubated soil cores:.

$\mathrm{k}_{\mathrm{wi} 30}=\mathrm{k}_{\mathrm{ci} 10} \mathrm{Q}_{10}^{\frac{\mathrm{T}-10}{10}}$

Where $\mathrm{k}_{\mathrm{wi} 30}$ is the decomposition rate of either the fast $(i=f)$ or the slow $(i=s) C$ pools obtained from

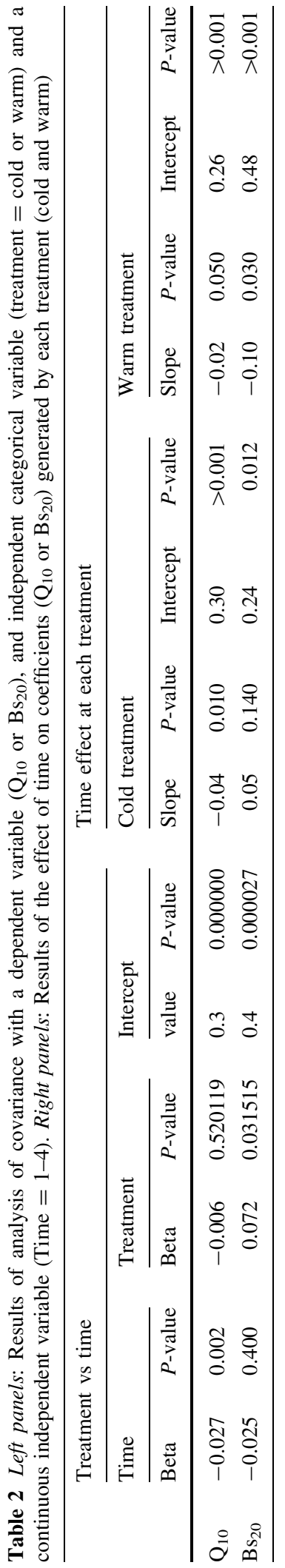




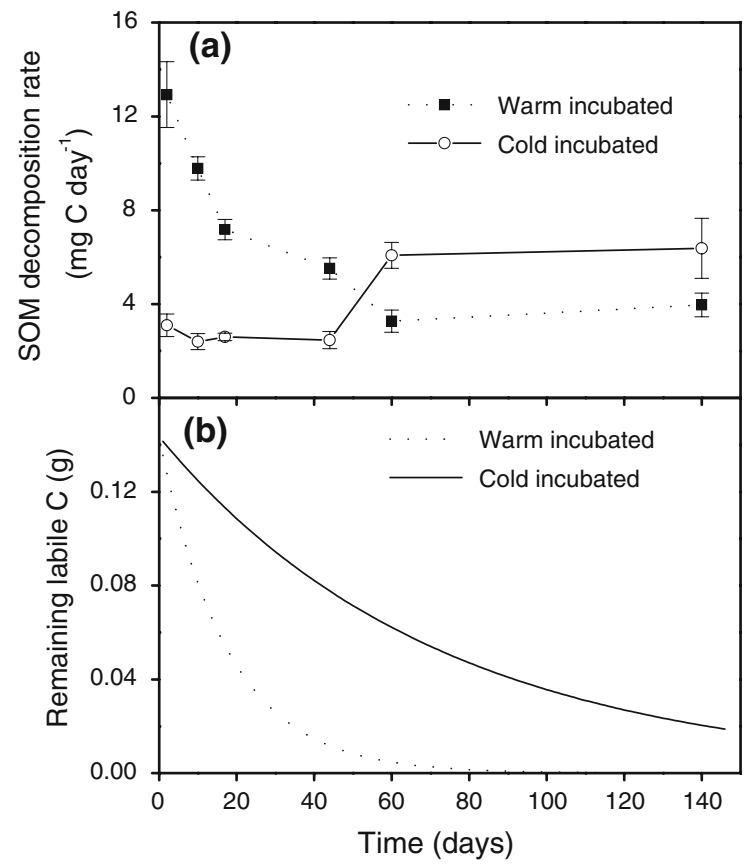

Fig. 1 a Microbial-mediated soil respiration for two different incubation temperatures, warm and cold, as a function of time. Error bars represent the standard error of the mean; $\mathbf{b}$ modeled available labile $\mathrm{C}$ fraction for the warm and the cold treatment of the study

the fit of Eq. 3 to respiration rates of warm-incubated soils (at $30^{\circ} \mathrm{C}$ ), $\mathrm{k}_{\mathrm{ci} 10}$ is the basal decomposition rate at a temperature of $10^{\circ} \mathrm{C}$, which coincided with coldincubation temperature. This basal decomposition rate was therefore used as the decomposition rate of the fast $(i=f)$ or the slow $(i=s) C$ pools for the cold-incubated soils. The value of $\mathrm{Q}_{10}$ was fixed at 2 and the value of $\mathrm{T}$ was 30 .

\section{Statistical analyses}

Analysis of co-variance was used to test significant differences in $\mathrm{Bs}_{20}$ and $\mathrm{Q}_{10}$ between and within both temperature treatments (i.e. warm $30^{\circ} \mathrm{C}$ and cold $10^{\circ} \mathrm{C}$ ). We carried out a null model likelihood ratio test for the significance of $\mathrm{Q}_{10}$ 's. We specifically tested the null hypotheses of no change in $\mathrm{Q}_{10}$ during the incubation $\left(\mathrm{H}_{0}=\mathrm{dQ}_{10}=0\right)$. For each treatment (warm or cold), the null model was fitted with all of available samples, and a sub-model was also fitted for each incubation time. A $\chi^{2}$ value was calculated with the logarithmic likelihood from the null model and the logarithmic likelihood from the model fitted at each incubation time. This statistic has an asymptotic $\chi^{2}$-distribution with $q$-1 degrees of freedom, where $q$ is the effective number of covariance parameters (those not estimated to be on a boundary constraint). If the probability $>\chi^{2}$ is $<0.05$, the null model is rejected. In other words, differences in parameters of the models fitted by incubation time are significant. Likelihood ratio test was performed by using the MIXED procedure of the standard statistical software package SAS (Version 9.1, SAS Institute Inc., Cary, NC, USA). Analysis of co-variance in STATISTICA, and were tested against a significance level of 0.05 .

\section{Results}

No biochemical differences between both warm and cold incubated cores were found at the beginning of the incubation (Table 1). Despite the similar initial substrate quantity and quality of both sets of soils (Table 1) respiration rates differed significantly between temperature treatments $\left(10\right.$ or $\left.30^{\circ} \mathrm{C}\right)$ (Fig. 1). Initial respiration rates of the warm-incubated soil cores were almost five times higher than those of the cold-incubated soil cores (Fig. 1a). Soil respiration decreased exponentially under warm conditions during the incubation period (Fig. 1a). Under warm temperatures respiration was highest when remaining $\mathrm{C}_{\mathrm{f}}$ was highest (Fig. 1a, b). Simulated depletion of labile $\mathrm{C}$, calculated from the coefficients obtained from Eq. 3 (warm incubations) and Eqs. 3 and 4 (cold incubations) also indicates that labile $\mathrm{C}$ pool was probably depleted faster in warm soils (Fig. 1b). This is because $\mathrm{k}_{\mathrm{f}}$, the decomposition rate of this fast $\mathrm{C}$ pool, was much higher for warm than for cold-incubated soils (Table 1).

Evolution of respiration rates under warm conditions were well explained by an exponential function (Fig. 2a). Under cold-conditions initial respiration rates were well explained by the decomposition rate obtained from warm incubated soils $\left(\mathrm{k}_{\mathrm{wf}}\right.$ and $\mathrm{k}_{\mathrm{ws}}$, respectively) and corrected for temperature (Eq. 4) (Fig. 2b). After 2 months of incubation, however, respiration rates at $10^{\circ} \mathrm{C}$ increased and were best explained by applying the $\mathrm{k}$ coefficients obtained under warm-incubations $\left(\mathrm{k}_{\mathrm{wf}}\right.$ and $\left.\mathrm{k}_{\mathrm{ws}}\right)$ (dotted line Fig. 2b).

Study of the short-term temperature response of microbial-mediated respiration rates indicates a 


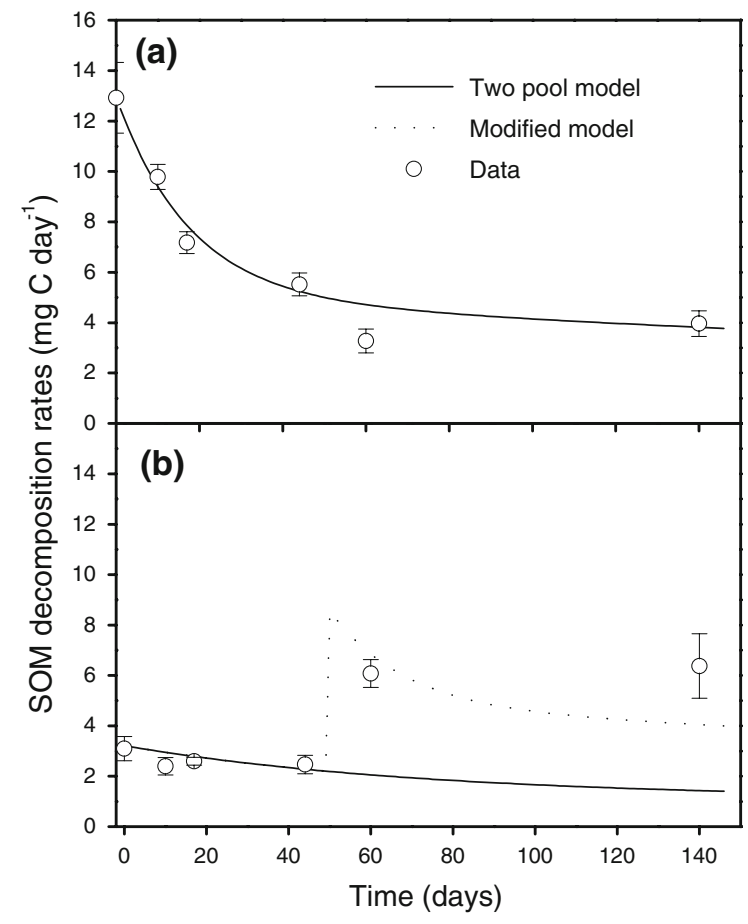

Fig. 2 a Modeled and measured microbial-mediated soil respiration for warm incubated soil cores as a function of time; b Modeled and measured microbial respiration for cold incubated soil cores as a function of time. Symbols represent observed respiration rates. Solid line in a represents modeled rates of soil respiration using Eq. 3. Solid line in $\mathbf{b}$ represents modeled rates of soil respiration of cold-incubated soils, using the $\mathrm{k}$ values obtained for warm soils (Eq. 3) corrected for temperature (Eq. 4). Dotted line in $\mathbf{b}$ represents the results of modeling cold incubation respiration rates using the warm incubated $\mathrm{k}$ values, not corrected by temperature. Error bars represent the standard error of the mean

general decrease in basal respiration rates $\left(\mathrm{Bs}_{20}\right)$ and the sensitivity to temperature $\left(\mathrm{Q}_{10}\right)$ with time (Table 2, Fig. 3). Likelihood ratio test of comparing the $\mathrm{Q}_{10}$ constant vs the $\mathrm{Q}_{10}$ varying model was statistically significant for both the warm and the cold treatment (data not shown), which confirmed the results obtained in Table 2. Ancova analyses with "treatment" (cold-warm) and "time" as independent variables indicated strong relation between "treatment" and $\mathrm{Bs}_{20}\left(\mathrm{Bs}_{20}\right.$ was significantly higher in cold than in warm-incubated soils) and between "time" and $\mathrm{Q}_{10}\left(\mathrm{Q}_{10}\right.$ decreased significantly with time). Within treatment, there was a strong effect of time over both $\mathrm{Bs}_{20}$ and $\mathrm{Q}_{10}$ (Table 2). $\mathrm{Bs}_{20}$ increased significantly in the cold treatment $(95 \%$ confidence interval) while in the warm treatment $\mathrm{Bs}_{20}$ decreased significantly $(P<0.0001)$. Intercept of the linear fit between "time" and $\mathrm{Bs}_{20}$ and $\mathrm{Q}_{10}$ coefficients further shows that temperature sensitivity $\left(\mathrm{Q}_{10}\right)$ at the beginning of the incubation were equal (1.9) for both set of soils, but $\mathrm{Bs}_{20}$ was more than double in the warm- than in the cold-incubated set of soils. The $\mathrm{Q}_{10}$ coefficient decreased significantly with time at both treatments (slope of the linear fit between "time" and $\mathrm{Q}_{10}$ significantly different from 0 ), at a $95 \%$ confidence interval (Table 2). The decrease was more pronounced under cold- than under warm incubated soils (Table 2) but as said above, likelihood ratio test confirmed that the decrease was statistically significant for both the warm and the cold treatment.

Glucose, the most common plant exudate (Grayston et al. 1996), was added to $C_{\mathrm{f}}$-depleted soils (incubated during 140 days at $30^{\circ} \mathrm{C}$ ) to study the effect in soil respiration and its sensitivity to temperature (Fig. 4). Addition of this energy-rich, nutrient-poor substrate caused a significant increase on $\mathrm{Bs}_{20}$ and $\mathrm{Q}_{10}$ to values similar to initial ones (compare Figs. 3a-4).

\section{Discussion}

In the studied soils, values of the easily decomposable pool $\left(\mathrm{C}_{\mathrm{f}}\right)$ (Table 1) were in the higher range of that observed in Rey and Jarvis (2006). This easily decomposable pool has been correlated to plant activity (Curiel Yuste et al. 2007), which was at its peak during the sampling date (see Materials and Methods). Active plants are continuously releasing organic material to soil in the form of easily decomposable substrate (exudates) such as simple sugars, amino acids and organic acids (Lynch and Whipps 1990; Grayston et al. 1996; Gleixner et al. 2005; Norton and Firestone 1991). It is therefore likely that the relatively large size of labile $\mathrm{C}$ pool in the studied soils could be partially attributed to the peak in plant activity at the sampling time.

Microbial-mediated soil respiration occurred faster at higher temperatures (Fig. 1a), as it has been shown in multiple experiments (e.g. Reichstein et al. 2000; Dalias et al. 2001). Under warm conditions, microbial-mediated respiration rates decreased exponentially in a very predictable way (Figs. 1a, 2a). Temporal evolution of microbial-mediated soil respiration could therefore be explained by first order kinetics: respiration was proportional to the amount 
Fig. 3 Short term temperature response curves of microbialmediated soil respiration rates at warm and coldincubated soils at different days after incubation began 10 (a), 17 (b), 60 (c) and 140 days (d). Error bars represent the standard error of the mean. All $P$-values obtained from the regressions were below the 0.005 significant level

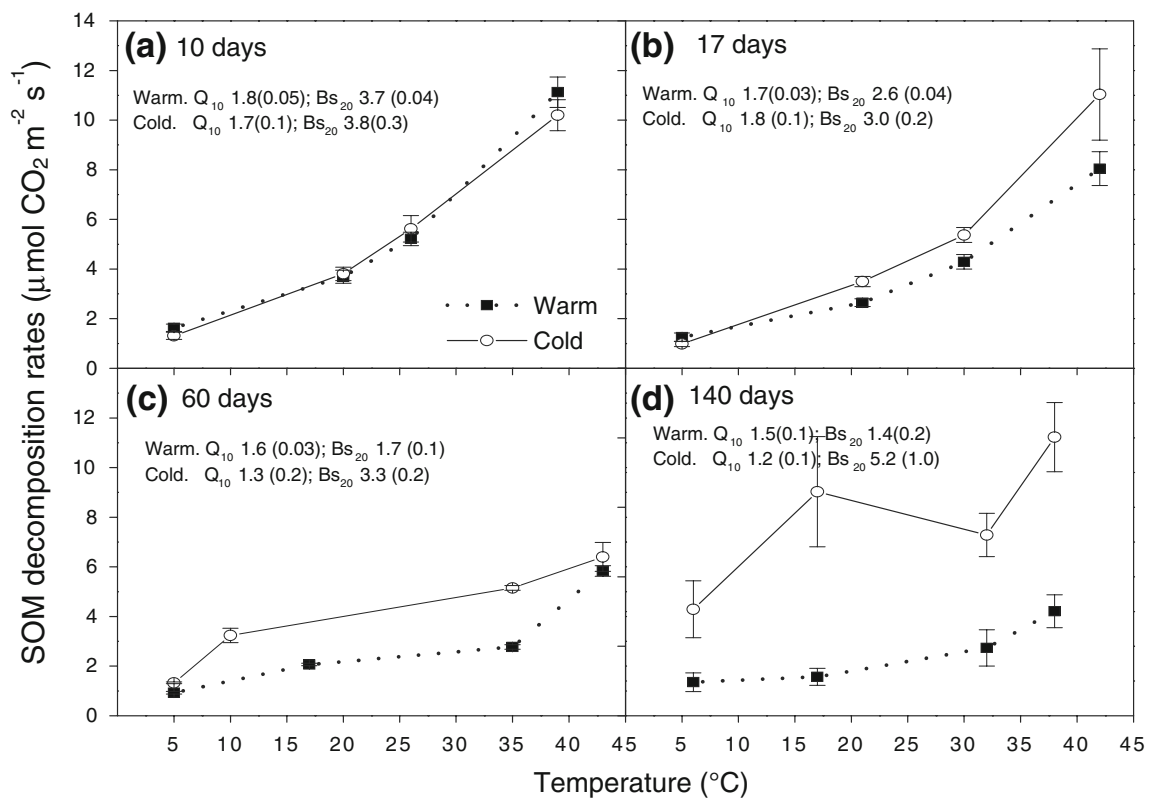

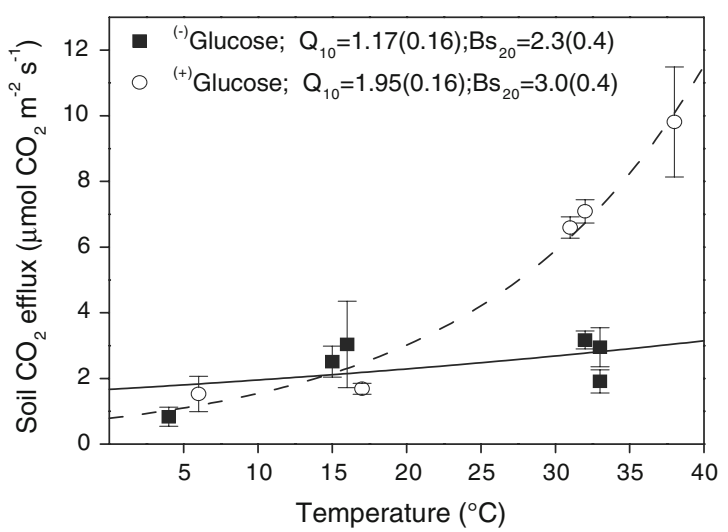

Fig. 4 Short term temperature response curves of microbialmediated soil respiration rates of warm-incubated soils before $((-)$ Glucose $)$ and after ((+) Glucose) addition of glucose solution. Error bars represent the standard error of the mean. Q10 values and standard error of the fit (parenthesis) are also provided

of a discrete number of $\mathrm{C}$ pools (two in the study case) and the decomposition rate of each $\mathrm{C}$ pool, which was temperature dependent (Fig. 2, Table 1). Respiration rates for a given temperature decreased gradually under the warm conditions of the incubation (Table 2, Fig. 3), which was reflected in decrease in temperature sensitivity $\left(\mathrm{Q}_{10}\right)$ and basal respiration rates $\left(\mathrm{Bs}_{20}\right)$ of warm incubated soils (Fig. 3). At the end of the incubation, both $\mathrm{Q}_{10}$ and $\mathrm{Bs}_{20}$ were significantly lower than at the beginning of the incubation (Table 2). It is a well known fact that respiration rates for a given temperature decreases as labile $\mathrm{C}$ fraction also decreases. However, the decrease in $\mathrm{Q}_{10}$ in absence or shortage of labile $\mathrm{C}$ disagrees with theory (e.g. Bosatta and Agren 1998), which states that temperature sensitivity of respiration should increase as the quality of SOM decreases. The increase in $\mathrm{Bs}_{20}$ and $\mathrm{Q}_{10}$ to values closer to initial values after addition of glucose - the most common plant exudates (Grayston et al. 1996)—(compare Figs. 3a-4) further confirms the idea of higher $\mathrm{Q}_{10}$ in presence of labile $\mathrm{C}$.

A number of observational 'deviations' from the kinetic theory (Liski et al. 1999; Luo et al. 2001; Fang et al. 2005) suggest, however, that the complexity of the process transcend a single theory (Davidson and Janssens 2006). Physical or biochemical accessibility to substrate by soil enzymes (Davidson et al. 2006; Davidson and Janssens 2006) may strongly affect the response to temperature of microbial decomposition of SOM and obscure the intrinsic temperature sensitivity of less labile fractions of SOM. Under the laboratory conditions of this experiment and after 4 months of incubation, the negative effect on $\mathrm{Q}_{10}$ caused by depletion of labile $\mathrm{C}$ and subsequent limitation in substrate accessibility to microbes and exo-enzymes was probably stronger than the positive effect on $\mathrm{Q}_{10}$ derived from decomposition of more recalcitrant SOM. Therefore we conclude that in natural ecosystems 
temperature sensitivity of microbial-mediated soil respiration would be primarily subjected to changes in the accessibility to an easily decomposable $\mathrm{C}$ pool rather than to changes in the intrinsic temperature sensitivity of the $\mathrm{C}$ pool being decomposed.

On the other hand, the increase in $\mathrm{Bs}_{20}$ and the decrease in $\mathrm{Q}_{10}$ after 60 days exposure to cold (Figs. 1a-3d) were unexpectedly pronounced. Substrate depletion probably occurred more slowly in these soils, as suggested by simulated depletion of labile $\mathrm{C}$ (Fig. 1b). The fairly constant $\mathrm{Bs}_{20}$ before day 60 and the increase in $\mathrm{Bs}_{20}$ after day 60 furthermore support this fact. The increase in $\mathrm{Bs}_{20}$ and the decrease in $\mathrm{Q}_{10}$ after 2 months of incubations were mainly caused by a strong increase in respiration rates at colder temperatures (Fig. 3) which could not be explained by a first-order kinetic model corrected for temperature (Fig. 2b). It must be pointed out that soils in this ecosystem rarely experienced cold temperatures. Average temperature at $2 \mathrm{~cm}$ depth in the mineral soil, 7 days prior to sample collection, was $15^{\circ} \mathrm{C}$. Mean annual temperature at this depth of soil profile was $19^{\circ} \mathrm{C}$ and temperatures similar to those of the incubation $\left(10^{\circ} \mathrm{C}\right)$ were only reached during the first month of 2005 ( $\sim 2$ months and a half before sampling). It is well known that microbes may experience physiological changes to become tolerant to cold conditions, e.g. maintenance of membrane fluidity or synthesis of cold-tolerant enzymes (Margesin et al. 2007). Moreover, microbial community structure changes under contrasting temperatures regimes, favoring microbes better adapted to the new temperatures (Zogg et al. 1997; Pettersson and Bååth 2003; Waldrop and Firestone 2004, 2006). Therefore it is possible that soil microbial community under cold conditions may have developed mechanisms of acclimation to these sub-optimal temperatures (cold-acclimation).

However, this observed transient doubling of respiration rates is just a singularity that disagrees with most of the laboratory observations at low temperatures reported to date (Reichstein et al. 2000; Dalias et al. 2001; Rey and Jarvis 2006). We nonetheless contend that the response observed in this study cannot be fully compared with previous observations where initial physical and biological conditions of soil were strongly modified by soil mixing, sieving, rewetting and/or oven drying. Manipulations such as sieving breaks up aggregates and makes available previously protected SOM, which increase initial respiration rates, with respect to intact cores (Hartley et al. 2007). Strong changes in soil water content (oven drying and rewetting) also affect microbial community composition (Lipson et al. 2002; Fierer et al. 2003), probably favoring opportunistic species over the endemic community (Allison 2005). This therefore suggests that other experiments should be similarly designed to refute/support our results.

Our experimental design therefore shows that: (1) under warm conditions, fast depletion of an easily accessible $\mathrm{C}$ pool affected negatively to both microbial-mediated soil respiration and its temperature sensitivity; and (2) microbial community, in this experiment, respired more for a given temperature with time (cold-acclimation). Our results open the controversy of whether soil respiration in a changing climate could be satisfactorily explained using simple first-order kinetics and fixed values of temperature sensitivity of soil respiration.

\section{Conceptual remarks}

Based on our results, Fig. 5 illustrates an example of how our perception of microbial-mediated soil respiration at a temperature reference $\left(\mathrm{Bs}_{\text {Tref }}\right)$ and its temperature sensitivity $\left(\mathrm{Q}_{10}\right)$ could be affected by environmental factors.

Under no water limitations, the temperature response curve of soil respiration would be primarily controlled by presence/absence of labile $\mathrm{C}$ carbon (Fig. 5a), which in natural ecosystems is provided by plants. This will affect the perception of $\mathrm{Bs}_{\text {Tref }}$ and $\mathrm{Q}_{10}$ on a fixed temperature range. Contrary to theory, this suggests that the negative effect on $\mathrm{Q}_{10}$ caused by depletion of an easily accessible $\mathrm{C}$ pool was probably stronger than the positive effect on $\mathrm{Q}_{10}$ derived from decomposition of more recalcitrant SOM. For the purpose of this study, these results suggest that models should take into account the effect of plantderived fresh $\mathrm{C}$ inputs to correctly understand temperature sensitivity of soil respiration.

When limitations in fresh labile $\mathrm{C}$ were not an issue, which was the case in the cold-incubated soils, microbial communities could increase their respiration rates at low temperatures (Fig. 5b). These adjustments resulted in strong changes in $\mathrm{Bs}_{\text {Tref }}$ and $\mathrm{Q}_{10}$ for a given temperature range. While current models allocate fixed 


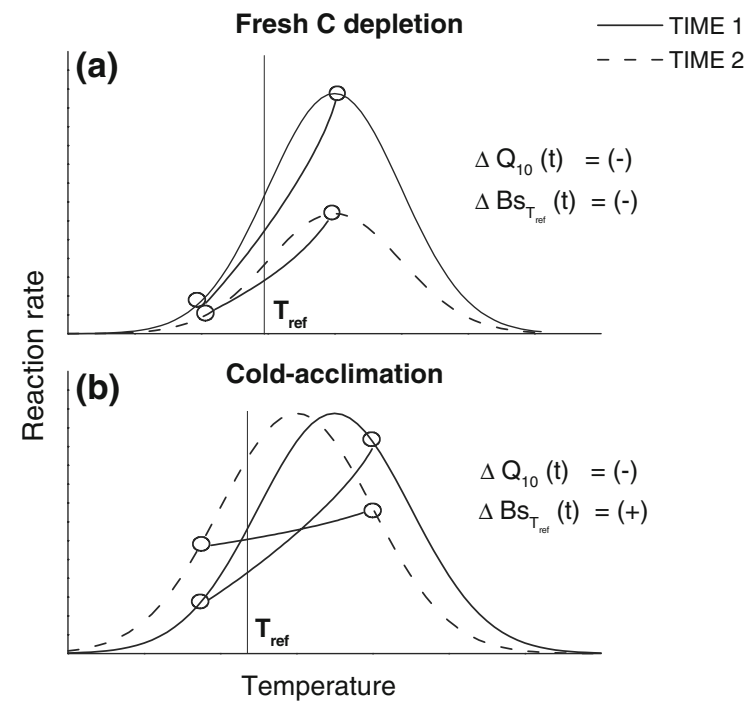

Fig. 5 Illustrative scheme of how the studied factors may affect $\mathrm{Q}_{10}$ and $\mathrm{Bs}_{\text {Tref }}$ for a given range of temperatures; The Figures represent a hypothetical temperature response curve for a given enzyme-driven process (which in the studied case was microbial-mediated soil respiration) on time 1 (initial conditions) and time 2 (final conditions). Solid lines represent the typical exponential curves used to represent temperature sensitivity of respiration. Curves were enclosed between two temperatures, one cold and one warm, represented by open circles. Text on the right side of the panels represents the trends of $\mathrm{Q}_{10}$ and $\mathrm{BS}_{\text {Tref }}$ from time 1 to time 2. Negative means net decrease and positive net increase of the coefficients $\left(Q_{10}\right.$ and $\mathrm{Bs}_{\text {Tref }}$ ) from time 1 to time 2, respectively. a Represents the effect of incubation time and warming over $\mathrm{Q}_{10}$ and $\mathrm{Bs}_{\text {Tref }}$. b Represents the effect of incubation time and cold-temperatures over $\mathrm{Q}_{10}$ and $\mathrm{Bs}_{\text {Tref }}$

$\mathrm{Q}_{10}$ 's and decomposition rate for a given SOM pool, we here show that microbial acclimation to cold temperatures may affect both, respiration rates for a given temperature and $\mathrm{Q}_{10}$ for a given temperature range. Future predictions of soil $\mathrm{CO}_{2}$ efflux can thus not be satisfactorily predicted if we do not understand patterns of microbial community acclimation to changing temperatures.

Acknowledgment This research was supported by the Kearney Soil Science Foundation and the US Department of Energy's Terrestrial Carbon Program, grant No. DE-FG03-00ER63013. These sites are members of the AmeriFlux and Fluxnet networks. J Curiel Yuste received a Marie Curie Intra-European Fellowship (EIF) from de European Union for project MICROCARB (FP62005-Mobility-5 \# 041409-MICROCARB) while conducting this research. We thank Ted Hehn for technical assistance during this experiment and Mr. Russell Tonzi for use of his ranch for this research. The author's also thanks to the subject editor and the three anonymous reviewers for their constructive comments. J. Curiel Yuste finally thanks Prof. Josep Penuelas and Dr. Roberto Molowny-Horas for their help and comments.

Open Access This article is distributed under the terms of the Creative Commons Attribution Noncommercial License which permits any noncommercial use, distribution, and reproduction in any medium, provided the original author(s) and source are credited.

\section{References}

Allison SD (2005) Cheaters, diffusion and nutrients constrain decomposition by microbial enzymes in spatially structured environments. Ecol Lett 8(6):626-635

Arrhenius S (1889) Über die Reaktionsgesechwindigkeit bei der Inversion von Rohrzucker durch Säuren. Zeitschrift für Physikalisch Chemie 4:226-248

Atkin OK, Tjoelker MG (2003) Thermal acclimation and the dynamic response of plant respiration to temperature. Trends Plant Sci 8:343-351

Atkin OK et al (2000) Acclimation of snow gum (Eucalyptus pauciflora) leaf respiration to seasonal and diurnal variations in temperature: the importance of changes in the capacity and temperature sensitivity of respiration. Plant Cell Environ 23:15-26

Balser TC, Firestone MK (2004) Linking microbial community composition and soil processes in a California annual grassland and mixed-conifer forest. Biogeochemistry 73(2):395-415

Bernal MP, Navarro AF, Sánchez-Monedero MA, Roig A, Cegarra J (1998) Influence of sewage sludge compost stability and maturity on carbon and nitrogen mineralization in soil. Soil Biol Biochem 30:305-313

Berry J, Bjorkman O (1980) Photosynthetic response and adaptation to temperature in higher-plants. Ann Rev Plant Physiol Plant Mol Biol 31:491-543

Bond-Lamberty B, Wang CK, Gower ST (2004) A global relationship between the heterotrophic and autotrophic components of soil respiration? Glob Chang Biol 10(10): $1756-1766$

Bosatta E, Agren GI (1998) Soil organic matter quality interpreted thermodynamically. Soil Biol Biochem 31(13): 1889-1891

Breland TA (1994) Enhanced mineralization and denitrification as a result of heterogeneous distribution of clover residues in soil. Plant Soil 166:1-12

Chen Q, Baldocchi D, Gong P, Kelly M (2006) Isolating individual trees in a savanna woodland using small footprint lidar data. Photogramm Eng Remote Sens 72:923-932

Cox PM, Betts RA, Jones CD, Spall SA, Totterdell IJ (2000) Acceleration of global warming due to carbon-cycle feedbacks in a coupled climate model. Nature 408(6813):750

Cramer W, Bondeau A, Woodward FI, Prentice IC, Betts RA, Brovkin V, Cox PM, Fisher V, Foley J, Friend AD, Kucharik C, Lomas MR, Ramankutty N, Sitch S, Smith B, White A, Young-Molling C (2001) Global response of terrestrial ecosystem structure and function to $\mathrm{CO}_{2}$ and 
climate change: results from six dynamic global vegetation models. Glob Chang Biol 7(4):357-373

Curiel Yuste J, Baldocchi DD, Gershenson A, Goldstein A, Misson L, Wong S (2007) Microbial soil respiration and its dependency on carbon inputs, soil temperature and moisture. Glob Chang Biol 13(9):2018-2035

Dalias P, Anderson JM, Bottner P, Couteaux MM (2001) Temperature responses of carbon mineralization in conifer forest soils from different regional climates incubated under standard laboratory conditions. Glob Chang Biol 7(2):181-192

Davidson EA, Janssens IA (2006) Temperature sensitivity of soil carbon decomposition and feedbacks to climate change. Nature 440(7081):165-173

Davidson EA, Janssens IA, Luo YQ (2006) On the variability of respiration in terrestrial ecosystems, moving beyond $\mathrm{Q}_{10}$. Glob Chang Biol 12(2):154-164

Eliasson PE, McMurtrie RE, Pepper DA et al (2005) The response of heterotrophic $\mathrm{CO}_{2}$ flux to soil warming. Glob Chang Biol 11(1):167-181

Fang CM, Smith P, Moncrieff JB, Smith JU (2005) Similar response of labile and resistant soil organic matter pools to changes in temperature. Nature 436(7052):881

Fierer N, Schimel JP, Holden PA (2003) Influence of dryingrewetting frequency on soil bacterial community structure. Microb Ecol 45:63-71

Fontaine S, Mariotti A, Abbadie L (2003) The priming effect of organic matter: a question of microbial competition? Soil Biol Biochem 35(6):837-843

Fontaine S, Barot S, Barre P, Bdioui N, Mary B, Rumpel C (2007) Stability of organic carbon in deep soil layers controlled by fresh carbon supply. Nature 450(8):277-280

Franzluebbers K, Weaver RW, Juo ASR, Franzluebbers AJ (1994) Carbon and nitrogen mineralization from cowpea plants part decomposing in moist and in repeatedly dried and wetted soil. Soil Biol Biochem 26:1379-1687

Friedlingstein P, Dufresne JL, Cox PM et al (2003) How positive is the feedback between climate change and the carbon cycle? Tellus B Chem Phys Meteorol 55(2):692-700

Giardina CP, Ryan MG (2000) Evidence that decomposition rates of organic carbon in mineral soil do not vary with temperature. Nature 404(6780):858-861

Gleixner G, Kramer C, Hahn V, Sachse D (2005) The effect of biodiversity on carbon storage in soils. In: SchererLorenzen M, Korner C, Schulze E-D (eds) Forest diversity and function: temperate and boreal systems. SpringerVerlag, Berlin, Germany, pp 165-183

Grayston SJ, Vaughan D, Jones D (1996) Rhizosphere carbon flow in trees, in comparison with annual plants: the importance of root exudation and its impact on microbial activity and nutrient availability. Appl Soil Ecol 5(1):29-56

Gu LH, Post WM, King AW (2004) Fast labile carbon turnover obscures sensitivity of heterotrophic respiration from soil to temperature: a model analysis. Glob Biogeochem Cycles 18(1):Art No GB1022

Hahn V, Högberg P, Buchmann N (2006) C-14 - a tool for separation of autotrophic and heterotrophic soil respiration. Glob Chang Biol 12(6):972-982

Hanson PJ, Edwards NT, Garten CT, Andrews JA (2000) Separating root and soil microbial contributions to soil respiration: a review of methods and observations. Biogeochemistry 48:115-146

Hartley IP, Heinemeyer A, Ineson P (2007) Effects of three years of soil warming and shading on the rate of soil respiration: substrate availability and not thermal acclimation mediates observed response. Glob Chang Biol 17:1761-1770

Hawkes CV, Wren IF, Herman DJ, Firestone MK (2005) Plant invasion alters nitrogen cycling by modifying the soil nitrifying community. Ecol Lett 8(9):976-985

Hogberg P, Nordgren A, Buchmann N, Taylor AFS, Ekblad A, Hogberg MN et al (2001) Large-scale forest girdling shows that current photosynthesis drives soil respiration. Nature 411(6839):789-792

Kätterer T, Reichstein M, Andrén O, Lomander A (1998) Temperature dependence of organic matter decomposition, a critical review using literature data analyzed with different models. Biol Fertil Soils 27(3):258-262

Kirschbaum MUF (1995) The temperature-dependence of soil organic matter decomposition, and the effect of global warming on soil organic-c storage. Soil Biol Biochem 27(6):753-760

Kirschbaum MUF (2004) Soil respiration under prolonged soil warming: are rate reductions caused by acclimation or substrate loss? Glob Chang Biol 10(11):1870-1877

Kuzyakov Y, Cheng W (2001) Photosynthesis controls of rhizosphere respiration and organic matter decomposition. Soil Biol Biochem 33(14):1915-1925

Kuzyakov Y, Cheng W (2004) Photosynthesis controls of CO2 efflux from maize rhizosphere. Plant Soil 263(1-2):85-99

Lipson DA, Schadt CW, Schmidt SK (2002) Changes in soil microbial community structure and function in an alpine meadow following spring snow melt. Microb Ecol 43: 307-314

Liski J, Ilvesniemi H, Makela A, Westman CJ (1999) $\mathrm{CO}_{2}$ emissions from soil in response to climatic warming are overestimated - The decomposition of old soil organic matter is tolerant of temperature. Ambio 28(2):171-174

Livingston GP, Hutchinson GL (1995) Enclosure-based measurement of trace gas exchange: applications and sources of error. In: Matson PA, Harris RC (eds) Biogenic trace gases: measuring emissions from soil and water. Blackwell Science, Oxford, pp 14-51

Luo YQ, Wan SQ, Hui DF et al (2001) Acclimatization of soil respiration to warming in a tall grass prairie. Nature 413(6856):622-625

Lynch JM, Whipps JM (1990) Substrate flow in the rhizosphere. Plant Soil 129(1):1-10

Margesin R, Neuner G, Storey KB (2007) Cold-loving microbes, plants, and animals-fundamental and applied aspects. Naturwissenschaften 94(2):77-99

McLauchlan KK, Hobbie SE (2004) Comparison of labile soil organic matter fractionation techniques. Soil Sci Soc Am J 68(5):1616-1625

Meir P, Cox P, Grace J (2006) The influence of terrestrial ecosystems on climate. Trends Ecol Evol 21(5):254-260

Misson L, Baldocchi DD, Black TA et al (2007) Partitioning forest carbon fluxes with overstory and understory eddycovariance measurements: a synthesis based on FLUXNET data. Agric For Meteorol 144(1-2):14-31 
Norton JM, Firestone MK (1991) Metabolic status of bacteria and fungi In: the rhizosphere of ponderosa pine-seedlings. Appl Environ Microbiol 57(4):1161-1167

Pettersson M, Bååth E (2003) Temperature-dependent changes in the soil bacterial community in limed and unlimed soil. FEMS Microbiol Ecol 45:13-21

Reichstein M, Bednorz F, Broll G, Kätterer T (2000) Temperature dependence of carbon mineralization: conclusions from a long-term incubation of subalpine soil samples. Soil Biol Biochem 32:947-958

Rey A, Jarvis P (2006) Modeling the effect of temperature on carbon mineralization rates across a network of European forest sites (FORCAST). Glob Chang Biol 12(10):1894-1908

Rustad LE, Campbell JL, Marion GM et al (2001) A metaanalysis of the response of soil respiration, net nitrogen mineralization, and aboveground plant growth to experimental ecosystem warming. Oecologia 126(4):543-562

Schimel J (1995) Ecosystem consequences of microbial diversity and community structure. In: Chapin FS, Korner C (eds) Arctic and alpine biodiversity: patterns, causes, and ecosystem consequences. Springer, Berlin, pp 239-254

Schimel JP, Gulledge J (1998) Microbial community structure and global trace gases. Glob Chang Biol 4(7):745-758

Sleutel S, De Neve S, Roibas MRP, Hofman G (2005) The influence of model type and incubation time on the estimation of stable organic carbon in organic materials. Eur J Soil Sci 56(4):505-514

Stark JM, Firestone MK (1996) Kinetic characteristics of ammonium-oxidizer communities in a California oak woodland-annual grassland. Soil Biol Biochem 28(10-11): 1307-1317

Stromgren M, Linder S (2002) Effects of nutrition and soil warming on stemwood production in a boreal Norway spruce stand. Glob Chang Biol 8(12):1195-1204
Tang JW, Baldocchi DD (2005) Spatial-temporal variation in soil respiration in an oak-grass savanna ecosystem in California and its partitioning into autotrophic and heterotrophic components. Biogeochemistry 73(1):183-207

Tang JW, Baldocchi DD, Xu L (2005) Tree photosynthesis modulates soil respiration on a diurnal time scale. Glob Chang Biol 11(8):1298-1304

Townsend AR, Vitousek PM, Desmarais DJ, Tharpe A (1997) Soil carbon pool structure and temperature sensitivity inferred using $\mathrm{CO}_{2}$ and ${ }^{13} \mathrm{CO}_{2}$ incubation fluxes from five Hawaiian soils. Biogeochemistry 38(1):1-17

Trumbore S (2000) Age of soil organic matter and soil respiration, Radiocarbon constraints on belowground $\mathrm{C}$ dynamics. Ecol Appl 10(2):399-411

Van 't Hoff JH (1898) Lectures on theoretical and physical chemistry. In: Chemical dynamics part I, Edward Arnold, London, pp 224-229

Waldrop MP, Firestone MK (2004) Altered utilization patterns of young and old soil $\mathrm{C}$ by microorganisms caused by temperature shifts and $\mathrm{N}$ addition. Biogeochemistry 67:235-248

Waldrop MP, Firestone MK (2006) Response of microbial community composition and function to soil climate change. Microb Ecol 52:716-724

$\mathrm{Xu}$ LK, Baldocchi DD (2004) Seasonal variation in carbon dioxide exchange over a Mediterranean annual grassland in California. Agric For Meteorol 123(1-2):79-96

Zogg GP, Zak DR, Ringelberg DB, MacDonald NW, Pregitzer KS, White DC (1997) Compositional and functional shifts in microbial communities due to soil warming. Soil Sci Soc Am J 61:475-481 